\title{
Study of maternal outcome in multiple gestation
}

\author{
Garima Girish Arora $^{1}$, Gourav Rajendrasingh Bagga ${ }^{2}$, Girish C. Arora ${ }^{3}$
}

\begin{abstract}
${ }^{1}$ Department of Obstetrics and Gynecology, ${ }^{2}$ Department of Radiology, Shri Vasantrao Naik Government Medical College and Hospital, Yavatmal, Maharashtra, India

${ }^{3}$ Paediatrics Consultant, ESI hospital, India
\end{abstract}

Received: 02 September 2016

Revised: 30 September 2016

Accepted: 01 October 2016

\author{
*Correspondence: \\ Dr. Garima Girish Arora, \\ E-mail: dreamgarima24@gmail.com
}

Copyright: () the author(s), publisher and licensee Medip Academy. This is an open-access article distributed under the terms of the Creative Commons Attribution Non-Commercial License, which permits unrestricted non-commercial use, distribution, and reproduction in any medium, provided the original work is properly cited.

\begin{abstract}
Background: Development of more than one fetus inside the uterus is called multifetal gestation or multiple pregnancy. It's a great challenge to the concerned obstetricians, due to late diagnosis and related complications. Ignorance on the part of patients themselves puts this group in great peril. The increase in multiple births increases the rate of maternal morbidity and mortality. Aims and objectives of the study were to study maternal outcome in patients with multiple gestation.

Methods: A prospective observational study carried out during the period of 1 year. A total of 200 patients with antenatal clinical and ultrasound confirmed diagnosis of multiple gestation were enrolled for the study. After taking proper consent for the study, proper history, clinical and obstetrical examinations were conducted and findings noted. Mothers were followed till discharge from the hospital.

Results: Most of the patients (49.5\%) were in 21-25 years age group. $65 \%$ of patients were multigravida. Undue enlargement of abdomen was the most common physical finding (62\%). 79\% patients had normal vaginal delivery. Fetal Malpresentation was the most common indication for caesarian section. A hypertensive disorder was the most common complication during pregnancy $(23.5 \%)$ and pre-term labour was the most common intra-partum complication (38\%). Incidence of maternal mortality was $1.5 \%$.

Conclusions: Multiple gestation is a mixed blessing and if successful, allows a couple to rapidly expand their family with a minimum number of pregnancies but it's a great challenge to the concerned obstetricians. Complications due to multiple gestation are associated with adverse maternal outcome.
\end{abstract}

Keywords: Multifetal gestation, Multiple pregnancy, Maternal outcome

\section{INTRODUCTION}

Procreation, the endless quality of reproduction and its regulation bestowed to all living cells by nature, irrespective of species or kind is miraculous. Multiple gestation is a mixed blessing and if successful, allows a couple to rapidly expand their family with a minimum number of pregnancies but it's a great challenge to the concerned obstetricians. The incidence of twins was found to occur is 1 in 80 pregnancies, triplets 1 in 6400
$(1: 80) .{ }^{1}$ Nowadays it is becoming a problem of increasing dimensions with the dramatic increase in numbers due to trend towards delayed child bearing and widespread use of assisted reproduction.

Development of more than one fetus inside the uterus is called multifetal gestation or multiple pregnancy, simultaneous development of two fetus (twin) is the commonest, although with newer infertility treatment protocols, development of 3-8 fetus have been reported. 
Factors influencing the frequency of dizygotic twining are maternal age, parity, race and ethnicity, conception soon after cessation of oral contraceptives, genetic predisposition and use of fertility enhancing therapies.

The body will change in first the same way as any expectant mother, but the discomforts of pregnancy are more marked due to greater needs of two developing babies, more emphasis is laid on certain nutrients like Iron, Calcium, folic acid and protein. During pregnancy there should be booking at good centre, monitoring of health and watch for signs of preterm labour. It is recommended every other week visits during the $2^{\text {nd }}$ trimester and once a week visit during the third trimester.

The increase in multiple births increases the rate of maternal morbidity and mortality. The main causes of maternal morbidity are preeclampsia, anemia, sepsis and postpartum bleeding. Several efforts are made to unify all types of contributions on twins into a new branch known as Gamellology. ${ }^{2}$

The conception, gestation and labour of plural pregnancy are certainly a challenge the outcome of which is determined by masterly intervention in antepartum, intrapartum and post-partum period. Thus it is important to conduct the study at this particular place to have awareness of risks and early detection which will guide the interventions. This might make allocation of scarce resources improper and prevent death of mothers of multiple pregnancy and their babies due to complications.

\section{METHODS}

A prospective observational study carried out during the period of 1 year from $1^{\text {st }}$ April 2014 to $31^{\text {st }}$ March 2015. A total of 200 patients with antenatal clinical and ultrasound confirmed diagnosis of multiple gestation were enrolled for the study. After taking proper consent for the study, patients were examined and findings noted with special reference to maternal age, parity, race and ethnicity, genetic predisposition and use of fertility enhancing therapies. Data is collected using a predesigned Proforma. Patients were followed within seven days. Those patients who were discharged early were asked to leave their mobile phone numbers or attend Obstetrics and Gynecology clinic at day seven.

\section{RESULTS}

The present study was carried out in Department of Obstetrics and Gynaecology, during 1stApril 2014 to $31^{\text {st }}$ March 2015. A total of 200 patients with multifetal gestation admitted in this period were included in this study.

Incidence of patients with multifetal Gestation during study period was $2.18 \%$. Incidence of twins was $2.14 \%$ and triplets $0.032 \%$. Highest incidence was found in the age group $21-25$ years $(49.5 \%)$ and least in the age group
$>35$ years $(2.5 \%)$. The $21-25$ years is the most common child bearing group in our hospital. 22 patients of less than 20 years had twins; this is because of marriage and conception at an early age in our country. In our study maximum twins were found in $65.5 \%$ and next to it were primigravida (60 cases). Grand multigravida constituted $4.5 \%$.

Table 1: Gestational age at the time of presentation.

\begin{tabular}{|lll|}
\hline Gestational age & No. of cases & Percentage \\
\hline$<28$ weeks & 17 & $8.5 \%$ \\
\hline $29-31$ weeks & 23 & $11.5 \%$ \\
\hline $33-34$ weeks & 17 & $8.5 \%$ \\
\hline $35-36$ weeks & 56 & $28.0 \%$ \\
\hline $37-40$ weeks & 87 & $43.5 \%$ \\
\hline
\end{tabular}

$56.5 \%$ cases presented before they reached the term, $43.5 \%$ patients reached 37 weeks or more.

Table 2: Physical findings at the time of admission.

\begin{tabular}{|llll|}
\hline $\begin{array}{l}\text { Sr. } \\
\text { No. }\end{array}$ & $\begin{array}{c}\text { No. of } \\
\text { Cases }\end{array}$ & Percentage \\
\hline 1 & $\begin{array}{l}\text { Undue enlargement of } \\
\text { abdomen }\end{array}$ & 124 & $62 \%$ \\
\hline 2. & $\begin{array}{l}\text { Multiple fetal parts } \\
\text { palpable }\end{array}$ & 80 & $40 \%$ \\
\hline 3. & Pallor & 40 & $20 \%$ \\
\hline 4. & Edema on feet & 46 & $23 \%$ \\
\hline 5. & Hypertension & 57 & $28.5 \%$ \\
\hline 6. & Excessive liquor & 08 & $4 \%$ \\
\hline 7. & Bleeding P/V & 09 & $4.5 \%$ \\
\hline 8. & Retained second twin & 04 & $2 \%$ \\
\hline
\end{tabular}

At the time of admission most common findings were undue enlargement of the abdomen $62 \%$, multiple fetal parts palpable $40 \%$, hypertension $28.5 \%$, Pallor $20 \%$, edema on feet $23 \%, 9$ patients presents with bleeding P/V out of which 3 patients came with retained second twin as second baby was in turned out to be placenta previa and 6 patients as abruptio placenta Transverse presentation for which LSCS was done.

Table 3: Distribution of cases A/c to mode of delivery.

\begin{tabular}{|llll|}
\hline $\begin{array}{l}\text { Sr. } \\
\text { no. }\end{array}$ & Type of delivery & $\begin{array}{l}\text { No. of } \\
\text { case }\end{array}$ & Percentage \\
\hline 1. & Vaginal delivery & 148 & $79.14 \%$ \\
\hline & $\begin{array}{l}\text { LSCS } \\
\text { (a) For both babies }\end{array}$ & 38 & $20.32 \%$ \\
& $\begin{array}{l}\text { (b) For second baby } \\
\text { only }\end{array}$ & 04 & $18.18 \%$ \\
\hline 3. & Obstetric hysterectomy & 01 & $0.13 \%$ \\
\hline
\end{tabular}

*12 abortions are excluded in this table 1 patient certify undelivered. 
Most of the patients had normal vaginal delivery $79.14 \%$ because of prematurity, multipara with good obstetric history .Incidence of LSCS was $20.32 \%$. 1 case had obstetric hysterectomy for rupture uterus.

Table 4: Indications of caesarean section $(n=38)$.

\begin{tabular}{|c|c|c|c|}
\hline $\begin{array}{l}\text { Sr. } \\
\text { no. }\end{array}$ & Indications & $\begin{array}{l}\text { No. of } \\
\text { case }\end{array}$ & Percentage \\
\hline 1. & Mal presentations & 22 & $57.89 \%$ \\
\hline 2. & Fetal distress & 04 & $10.52 \%$ \\
\hline 3. & Non progress of labour & 03 & $7.89 \%$ \\
\hline 4. & $\begin{array}{l}\text { Previous } 2 \text { LSCS with } \\
\text { scar dehiscence }\end{array}$ & 03 & $7.89 \%$ \\
\hline 5. & $\begin{array}{l}\text { Previous caesarean with } \\
\text { decreased scar thickness }\end{array}$ & 02 & $5.263 \%$ \\
\hline 6. & Obstructed labour & 02 & $5.263 \%$ \\
\hline 7. & Major Placenta Previa & 01 & $2.63 \%$ \\
\hline 8. & $\begin{array}{l}\text { Previous caesarean with } \\
\text { PROM }\end{array}$ & 01 & $2.63 \%$ \\
\hline
\end{tabular}

Commonest indication for caesarean in our study was Malpresentation. $57.89 \%$, out of which Breech in $1^{\text {st }}$ baby accounts for $2.63 \%$ and transverse lie in $1^{\text {st }}$ baby accounts for $13.15 \%$. In the remaining cases, breech vaginal delivery was preferred most commonly because of marked prematurity congenital malformation, multipara with good obstetric history and in those who came with cervix nearly fully dilated.

\section{Table 5: Maternal complications during pregnancy} and labour.

\begin{tabular}{|llll|}
\hline $\begin{array}{l}\text { Sr. } \\
\text { no. }\end{array}$ & $\begin{array}{l}\text { Nomplication } \\
\text { case }\end{array}$ & Percentage \\
\hline & During pregnancy & & \\
\hline 1 & Hypertensive disorder & 57 & $23.5 \%$ \\
\hline 2. & Anaemia & 40 & $20 \%$ \\
\hline 3. & PROM & 17 & $8.5 \%$ \\
\hline 4. & APH & 09 & $4.5 \%$ \\
\hline 5. & Poly-hydramnios & 08 & $4.0 \%$ \\
\hline 6. & Oligo-hydramnios & 02 & $1.0 \%$ \\
\hline 7. & Viral hepatitis & 03 & $1.5 \%$ \\
\hline & During labour & & \\
\hline 1. & Preterm labour & 76 & $38.0 \%$ \\
\hline 2. & Atonic PPH & 16 & $8.0 \%$ \\
\hline 3. & Rupture uterus & 01 & $0.5 \%$ \\
\hline & Maternal deaths & 03 & $1.5 \%$ \\
\hline
\end{tabular}

The most common complications during pregnancy were hypertensive disorders $28.5 \%$ and anaemia $20 \%$.

Table 6: The incidence of maternal mortality.

\begin{tabular}{|llll|}
\hline Sr. no. & & No. of case & Percentage \\
\hline 1 & Total no. of cases & 200 & \\
\hline 2. & No. of mortalities & 03 & $1.5 \%$ \\
\hline
\end{tabular}

Out of 57 cases 25 cases were of gestational hypertension, 30 cases were of preeclampsia, 1 eclampsia and 1 chronic hypertension.

There were total 3 mortalities in study period. The incidence of maternal death in our study was $1.5 \%$.

Table 7: Analysis of maternal mortality.

\begin{tabular}{|c|c|c|c|c|}
\hline $\begin{array}{l}\text { Sr. } \\
\text { no. }\end{array}$ & Diagnosis & $\begin{array}{l}\text { Obstetric } \\
\text { history }\end{array}$ & $\begin{array}{l}\text { Mode of } \\
\text { delivery }\end{array}$ & $\begin{array}{l}\text { Cause of } \\
\text { death }\end{array}$ \\
\hline 1. & $\begin{array}{l}\text { Full term } \\
\text { pregnancy with } \\
\text { labour pains with } \\
\text { twins with pre- } \\
\text { eclampsia }\end{array}$ & G3P2L2 & Vaginal & $\begin{array}{l}\text { Pulmonary } \\
\text { embolism }\end{array}$ \\
\hline 2. & $\begin{array}{l}\text { ANC } 34 \text { weeks } \\
\text { pregnancy with } \\
\text { twins with pre- } \\
\text { eclampsia with } \\
\text { IUFD with severe }\end{array}$ & G2P1A0L1 & - & $\begin{array}{l}\text { Cardiac } \\
\text { failure }\end{array}$ \\
\hline 3. & $\begin{array}{l}\text { Full term } \\
\text { pregnancy with } \\
\text { labour pains with } \\
\text { triplets with pre- } \\
\text { eclampsia with } \\
\text { severe anaemia } \\
\text { with CCF with } \\
\text { pulmonary edema }\end{array}$ & G2P0A1L0 & Vaginal & $\begin{array}{l}\text { Pulmonary } \\
\text { edema }\end{array}$ \\
\hline
\end{tabular}

All the 3 patients were multigravida 2 delivered vaginally and 1 was undelivered.

\section{DISCUSSION}

Development of more than one fetus inside the uterus is called multifetal gestation or multiple pregnancies. It's a great challenge to the concerned obstetricians, due to late diagnosis and related complications. Ignorance on the part of patients themselves puts this group in great peril. The increase in multiple births increases the rate of maternal morbidity and mortality.

$56.5 \%$ cases presented before they reached the term, $43.5 \%$ patients reached 37 weeks or more. In Katke and Thakre report $48.44 \%$ patients delivered between 33-36 weeks. ${ }^{3}$ Percentage of patients delivering between 33-36 weeks by dates was higher $25.5 \%$ as compared to Bhoraskar's study (13.1\%). As compared to various authors, the average weeks of gestation are very similar and comparable with our study i.e. 35 weeks, as the average weeks of gestation among twins being 36 weeks by Kauppila et al and 33 weeks by Erdemoglu et al and 34 weeks by Yuel et al.

Undue enlargement of the abdomen was the most common presenting complaint followed by maternal hypertension and palpation of multiple fetal parts.

Most of the patients had normal vaginal delivery $79.14 \%$ because of prematurity, multipara with good obstetric history. Incidence of LSCS was $20.32 \%$. 1 case had 
obstetric hysterectomy for rupture uterus while Thompson reported incidence of LSCS as high as $45 \%$ and Katke and Thakre study had maximum number of vaginal deliveries, Twin 1 (53.125\%), Twin $2(50 \%)$, and LSCS was required for $46.875 \%$ of twin1 and $50 \%$ of Twin $2 .^{3}$ Yuel et al had $55 \%$ vaginal deliveries and $45 \%$ caesarean sections. ${ }^{6}$ In study by Erdemoglu et al $50.5 \%$ had vaginal deliveries and $45 \%$ required caesarean section. $^{5}$

Commonest indication for caesarean in our study was Malpresentation. $57.89 \%$, out of which Breech in $1^{\text {st }}$ baby accounts for $2.63 \%$ and transverse lie in $1^{\text {st }}$ baby accounts for $13.15 \%$. Katke and Thakre study, Malpresentation in twins $(43.75 \%)$ was the major indication for LSCS. ${ }^{3}$ The presence of breech or transverse lie of any of the fetuses increased the chances of LSCS.

The most common complications during pregnancy were hypertensive disorders $28.5 \%$ and anaemia $20 \%$. The incidence of preeclampsia, as reported by various authors is Joseph 27\%, Jacob Bhargava 31.9\%, Tempe and Batra $36.25 \%$, Bhoraskar $22.8 \%$. In our study incidence of preeclampsia was $15 \% .^{7-9}$

Out of 40 cases of anaemia, 32 were moderate anemia and 8 of severe degree. Various authors have reported an incidence of anemia in twins as Guttamacher, Spellacy $40 \%$, Tempe and Batra $34.5 \%$, Bhoraskar as $31.9 \% .^{9-11}$

The incidence of hydramnios in our study was $47 \%$ while Newton ER 12\%, Bhoraskar - 9.6\%, Bhatia-10.5\%, Patel $10 \%$, Jacob and Bhargava 9.5\%. ${ }^{8}$ APH was found in 9 cases $(4.5 \%) .^{12-14}$ In 3 cases it was placenta previa and 6 cases were abruptio placenta, Newton- 2.6\%, Joseph $2.8 \%$, Jacob and Bhargava 3.3\%, Bhoraskar- 2\%, Tempe and Batra $7.0 \% .^{7-9,12}$

During labour, the most important complication in our study was preterm labour found in $38 \%$ cases. Morale WJ also reported incidence as high as $60 \% .^{15}$ Incidence of PPH was $8 \%$ in our study. Blood transfusion was required in 10 cases, Bhoraskar- $3.59 \%$, Jacob and Bhargava-2.7\%, Tempe and Batra- $4 \%{ }^{8,9}$ The incidence of maternal death in our study was $1.5 \%$.

All the 3 patients were multigravida 2 delivered vaginally and 1 was undelivered. All the 3 patients were unbooked and referred patients. Pulmonary embolism was the unavoidable cause, but the pulmonary edema and cardiac failure due to severe anemia were avoidable, but due to late referral, they can't be avoided.

\section{CONCLUSION}

Multiple gestation is a mixed blessing and if successful, allows a couple to rapidly expand their family with a minimum number of pregnancies but it's a great challenge to the concerned obstetricians. Complications due to multiple gestation are associated with adverse maternal outcome.

\section{Funding: No funding sources}

Conflict of interest: None declared

Ethical approval: The study was approved by the Institutional Ethics Committee

\section{REFERENCES}

1. Cunningham FG. William obstetrics. McGraw Hill; $23^{\text {rd }}$ edn. 2010:859-888.

2. Jewell SE, Yip R. increasing trends in plural births in U.S.-obstet. Gynecol. 1995;85:229-32.

3. Katke RD, Thakre NN. Multifetal Pregnancy: Maternal and Neonatal Outcome. Obstet Gynecol Int J. 2015;3(1):1-7.

4. Kauppila A, Jaupilla P, Koivisto M, Moilanen I, Ylikorkala O. Twin Pregnancy A clinical study of 335 cases. Acta Scand Eng. 1973;13(64).

5. Erdemoglu M, Kale A, Akdeniz N, Yalinkaya A, Ozcan Y. Retrospective Analysis of Multiple Pregnancies. Perinatal Journal. 2005;13(4).

6. Yuel VI, Kaur V. An analytical study of pregnancy outcome in multifetal gestation. J Obstet Gynecol India. 2007;57(6):509-12.

7. Joseph K. Perinatal Mortality in twin pregnancy. Obstetrics and Gynecology: Wolters Kluwer; May 1964:23;5:738-44

8. Bhargava J. Review of 291 cases of multiple pregnancy. J Obstet Gynecol. 1973;23:302-11.

9. Tempe A, Batra S, Nankana J. Twin versus singleton pregnancy: A comparison of morbidity and mortality. J. Obstet. Gynecol. Ind. 1993;43,4:518-23.

10. Guttamcher AF. An analysis of 521 cases of twin pregnancy. Differences in single ovum and double ovum twinning, Am J Obstet Gynaecol. 34:76-84.

11. Spellacy WN, Handler A, Ferre CD. A case control study of 1253 twin pregnancies from 1982-1987 prenatal data base. Obstet Gynecol. 1990;75:168.

12. Newton ER. Antepartum care in multiple gestation. Semin Perinatol. 1986;10(1):19-29.

13. Bhatia G. Twin pregnancy of 500 cases. Obstet Gynecol. 1978;57:25.

14. Patel F, Hall DR. Twin pregnancies, risks and complications: a review article. Obstetrics and Gynecology Forum. 2004;14(3):13-9.

15. Morales WJ, Angel JL, O'Brien WF, Knuppel RA. Use of ampicillin and corticosteroids in premature rupture of membranes: a randomized study. Obstet Gynecol. 1989;73(5,1):721-6.

Cite this article as: Arora GG, Bagga GR, Arora GC. Study of maternal outcome in multiple gestation. Int J Reprod Contracept Obstet Gynecol 2016;5:3931-4. 